\title{
37. PALYNOLOGY OF SITES 358, 356, 355 DSDP, LEG 39, SOUTHWESTERN ATLANTIC OCEAN
}

\author{
N.S. Ioannides and J.P. Colin, Esso Production Research-European Laboratories 213, \\ cours Victor Hugo, Begles, France
}

\begin{abstract}
SUMMARY
The palynology of 45 samples from DSDP Sites 355,356 , and 358 is briefly discussed. Owing to the scarcity of the palynomorphs recovered, the tentative ages given are based on individual occurrences rather than assemblages. The material studied from Site 358 ranges in age from late Eocene to late Oligocene; the material from Site 356 is undifferentiated upper Cretaceous (possible Senonian). No diagnostic elements were obtained from Site 355 . The majority of species recorded are illustrated, systematic descriptions are not presented in this paper.
\end{abstract}

\section{INTRODUCTION}

Leg 39 drilling along the eastern margin of Brazil provided the opportunity to investigate the palynology of a wide variety of sediments. The present report summarizes the palynological analyses from borehole material cored at Sites 355, 356 and 358 (Figure 1). Site 358 is in the northeastern part of the Argentine Basin at $37^{\circ} 39.31^{\prime} \mathrm{S}, 35^{\circ} 57.82^{\prime} \mathrm{W}$. The main sedimentary types penetrated, through intermittent coring, are radiolarian, siliceous, and ferruginous mudstones and marly chalks. Site 355 is in the Brazil Basin at $15^{\circ} 42.59^{\prime} \mathrm{S}$, $30^{\circ} 36.03^{\prime} \mathrm{W}$. The sedimentary sequence comprises a thick accumulation of zeolitic clays, underlain by a thin deposit of calcareous sediment which, in turn, overlies a fractured and weathered basaltic basement. Site 356 is on the São Paulo Plateau at $28^{\circ} 17.22^{\prime} \mathrm{S}, 41^{\circ} 05.28^{\prime} \mathrm{W}$. The deposits penetrated range from marly chalk and mudstone to conblomeratic clays. Further details are included in the Site Report chapters of this volume.

\section{SAMPLE PREPARATION}

The rock samples were prepared by means of standard palynological techniques using hydrofluoric acid followed, if necessary, by slight oxidation with concentrated nitric acid. Slides are kept in the palynological collection of EPR-E, Bordeaux. The coordinates given are those taken on a Zeiss photomicroscope I, No. 52348 .

\section{COMPOSITION AND AGE OF ASSEMBLAGES}

The stratigraphic distribution of the palynomorphs obtained from all three sites is plotted in Figure 2. Fifty-five samples were prepared for palynological investigation. Samples were taken from those intervals for which age assignment by means of other fossil groups, such as foraminifers, coccoliths, and radiolarians, proved difficult. The occurrence of palynomorphs was very limited: the majority of samples are barren or contain only scarce specimens. In fact, most of the species recorded were encountered sporadically in the preparations. Preservation of microfossils varies

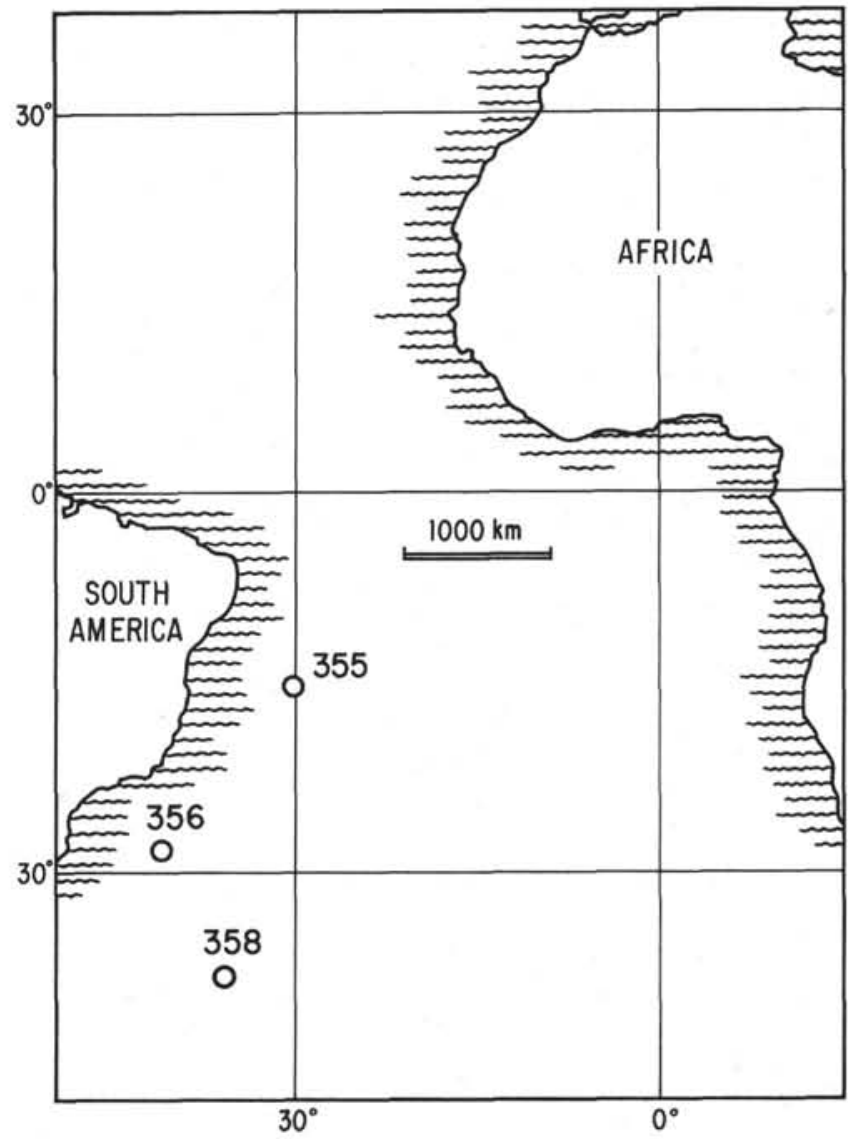

Figure 1. Locations of Sites 355, 356, and 358, DSDP Leg 39.

from good to extremely poor; the spores are generally better preserved. For these reasons, numerical analyses and detailed correlations with other areas were not attempted. Instead, tentative ages are given, and these are mostly based on individual occurrences. From the meager evidence available it was not possible to draw any conclusions concerning paleogeography, although 


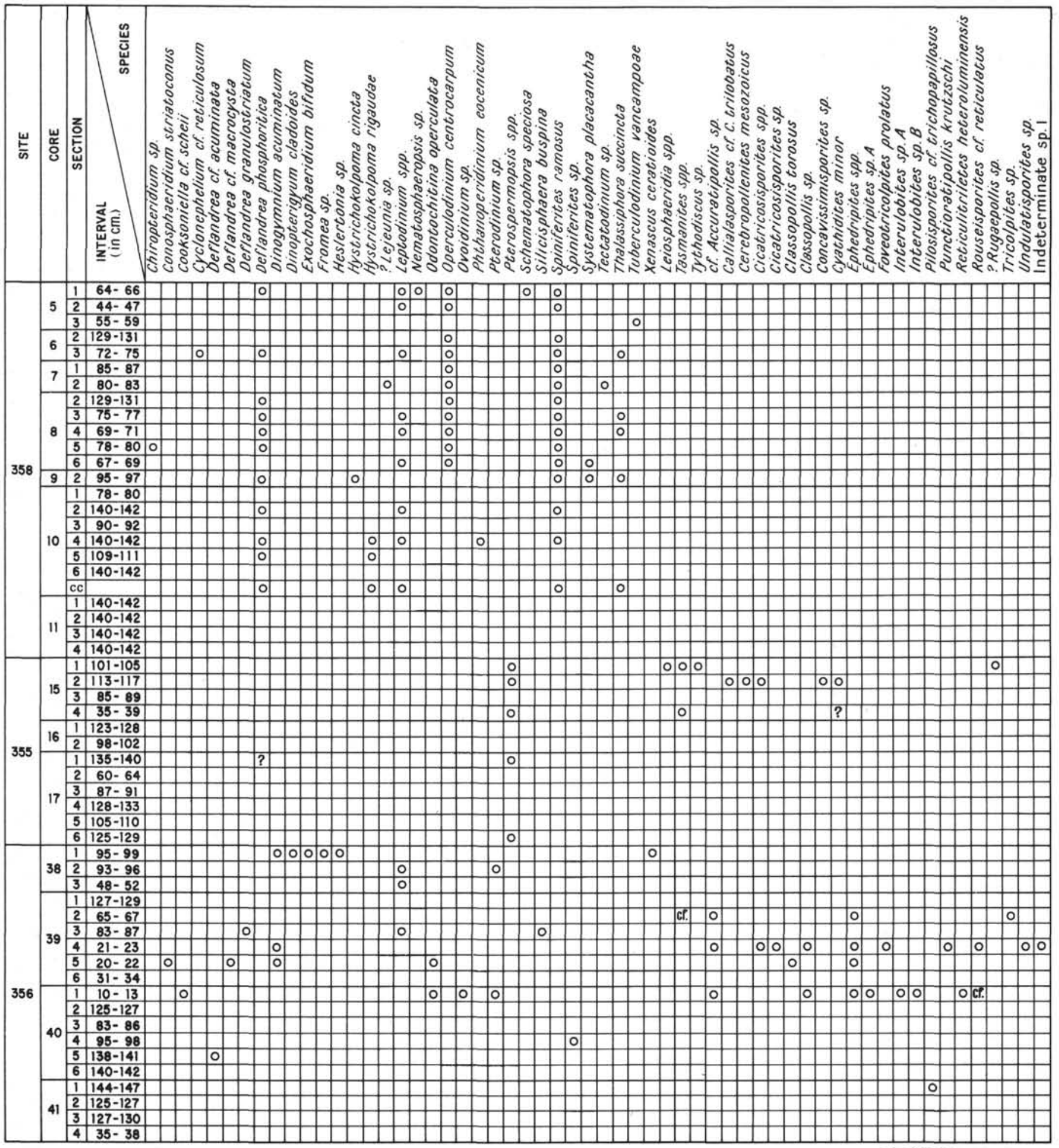

Figure 2. Stratigraphic distribution of polynomorphs obtained from Sites 355, 356, and 358.

on a very broad basis some similarities are manifest between this area and the western margin of equatorial Africa (Gabon, for example).

\section{SITE 358}

The assemblages from Site 358 show little diversity; only 16 taxa were recorded. Spiniferites and Operculodinium centrocarpum are fairly represented. The general lack of terrestrially derived microfossils, and the limited diversity of the microplankton population suggest an open marine depositional environment.

Core 11 proved to be barren, whereas Core 10 yielded Deflandrea phosphoritica, Hystrichokolpoma rigaudae, Thalassiphora succincta, and Phthanoperidinium eocenicum. The occurrence of the last form may suggest a late Eocene age (Section 4). 
Cores 9 and 8 collectively contain Deflandrea phosphoritica, Hystrichokolpoma cinctum, Operculodinium centrocarpum, Systematophora placacantha, Thalassiphora succincta, and a badly preserved specimen of Chropteridium sp. An Oligocene age is assigned to this interval.

Core 7 yielded no stratigraphically significant elements, including such elements as Operculodinium centrocarpum, Tectatodinium sp., and a single record of a form provisionally attributed to Lejeunia; the last species is possibly derived from upper Cretaceous sediments. A reasonable assemblage was obtained from Section 358-6-3. It includes Cyclonephelium cf. reticulosum, Deflandrea phosphoritica, Operculodinium centrocarpum, and Thalassiphora succincta. On the basis of the presence of $T$. succincta, presently known from Oligocene sediments, and $C$. cf. reticulosum (type described from the middle-upper Oligocene), a tentative Oligocene age may be assigned to this assemblage.

Core 5 contains Deflandrea phosphoritica, Tuberculodinium vancampoae, and Schematophora speciosa. The presence of both $D$. phosphoritica, a species to date not recorded from Miocene sediments, and $T$. vancampoae, a form unknown from deposits older than upper Oligocene, may indicate a late Oligocene age. The presence of $S$. speciosa in Section 5-1 is unusual. This species is generally considered to be absent from rocks younger than Eocene, although it has been questionably recorded from the middle Miocene of Australia.

\section{SITE 355}

Site 355 proved to be least fossiliferous of the three sites studied. Nearly all samples are devoid of any type of acid-insoluble microfossils, and only sparse organic matter was obtained in the preparations. Most palynomorphs obtained were referred to as Pterospermopsis spp., and no attempt was made to differentiate them to species level. Tasmanites spp., Tythodiscus sp., Leiosphaeridia spp., scattered specimens of ?Rugaepollis $\mathrm{sp}$., and some possible derived Cretaceous forms constitute the rest of the assemblages. Dinoflagellates are absent, with the exception of Section 355-17-1 which yielded two questionable records of Deflandrea phosphoritica (a species confined to the Eocene and Oligocene). This assemblage is too limited for any definite stratigraphic conclusion to be drawn, but a marine depositional environment is indicated, at least for the interval represented by Core 355-15.

\section{SITE 356}

The assemblages obtained from this site are very restricted, both numerically and in diversity. Hence, only broad generalizations can be made concerning their stratigraphic significance.

The microflora is a mixture of terrestrially derived micro-fossils and marine microplankton, accompanied by abundant wood matter. Although reworking from older rocks appears to have considerably contributed to the composition of the assemblages (as at Site 355), the above characteristics suggest that the sediments were not deposited far from land. Core $356-41$ is virtually devoid of any type of palynomorph with the exception of scarce speciments apparently derived from older sediments, and certain spheres of unknown affinity (?algal). Only the topmost sample of Core 356-40 (Section 1) can be considered rich in palynomorphs. Interesting is the occurrence of Reticulitriletes heteroluminensis, a species recently described from the Cenomanian of Gabon (Boltenhagen 1975b), and Ephedripites sp., a highly distinctive upper Cretaceous/lower Tertiary form with spiral ridges frequently illustrated in the Russian literature. Another important occurrence is of a "triporosulcate" species tentatively referred to Accuratipollis Chlonova, 1961. This palynomorph seems to be structurally related to the Tertiary genus Anaculosidites (Cookson and Pike) Potonie, 1960. The type of Accuratipollis was originally reported from the upper Cretaceous of Western Siberia, but forms exhibiting similar morphological characters have also been described from equatorial Africa (e.g., from Gabon, by Belsky and Boltenhage, 1963).

The above data cannot provide an age more precise than Late Cretaceous. Core 39 contains the richest assemblages at this site. Besides other species, it contains Dinogymnium (D. acuminatum), a genus unknown below the upper Coniacian, Deflandrea granulostriatum, reported from the Maestrichtian of the Senegal Basin and upper Senonian of Eastern Brazil (Herngreen, 1975b), Punctioratipollis krutzschi, recently described from the Turonian of Gabon (Boltenhagen, 1975a), Foveotricolpites prolatus from the upper Senonian of Eastern Brazil (Herngreen, 1975a), and Silicisphaera buspina, a new form recorded from Turonian and Senonian deposits. As a whole, this assemblage may justify a Senonian age, probably not older than upper Coniacian.

The assemblage obtained from the top of Core 38 is sparse. Dinopterygium cladoides, D. acuminatum, and Xenascus ceratioides are the most significant elements. A Senonian age, probably younger than upper Coniacian, may be assigned to this interval.

\section{ACKNOWLEDGMENTS}

The authors are grateful to Dr. H.P. Luterbacher for providing the samples, Dr. W.C. Elsik for his valuable comments on the names of some spores and pollen, and Dr. J.P. Verdier for discussion.

They would also like to express their appreciation to Esso Production Research-European Laboratories, France, for permission to publish this paper.

\section{REFERENCES}

Belsky, C.Y. and Boltenhagen, E., 1963. Sporomorphes de position taxonomique incertaine du Crétacé Supérieur du Gabon: Grana Palynologica, v. 4, p. 262-270.

Boltenhagen, E., 1975a. Pollen périporé du Crétacé Supérieur du Gabon: Rev. Micropal., v. 17, p. 164-170. 1975b. Quelques spores du Crétacé Supérieur du Gabon: Rev. Micropal., v. 18, p. 69-80.

Herngreen, G.F.W., 1975a. An upper Senonian pollen assemblage of borehole 3-PIA-10-AL state of Alagoas, Brasil: Pollen and Spores, v. 17, p. 93-140. 1975b. Palynology of Middle and Upper Cretaceous strata in Brasil: Med. Rijks. Geol. Dienst. Nieuwe Ser., v. 26 , p. $39-90$. 
Lentin, J.K. and Williams, G.L., 1973. Fossil dinoflagellates: Index to genera and species. Geol. Surv. Canada, paper 73-42, p. 1-176.

Millioud, M.E., Williams, G.L. and Lentin, J.K., 1975. Stratigraphic range charts: Selected Cretaceous dinoflagellates. A.A.S.P., Contrib. series no. 4, p. 65-71.
Morgenroth, P. 1966a. Mikrofossilien und Konkretionen des nordwesteuropäischen Untereozäns: Palaeontographica Abt. B, v. 119 , p. 1-53.

1966b. Neue in organischer Substanz erhaltene Mikrofossilien des Oligozäns: Neues Jahrb. Geol. Paleontol., Abh., v. 127, p. 1-12. 

PLATE 1

All figures $\times 750$

Figure 1 Tectatodinium $\mathrm{sp}$.

Specimen showing precingular archaeopyle: Section $358-7-2 ; 105668$

Figure $2 \quad$ Nematosphaeropsis $\mathrm{sp}$.

Section 358-10-4; SL. 1:1095112.

Figure 3 Operculodinium centrocarpum (Deflandre and Cookson) Wall, 1967.

Precingular archaeopyle upwards; Section 358-6-3; 940139.

Figure 4 Phthanoperidinium eocenicum (Cookson and Eisenack) Lentin and Williams, 1973.

Section 358-10-4; SL. 1:1158208.

Figure 5 Spiniferites ramosus (Eisenack) Loeblich and Loeblich, 1966.

Section 358-5-1; 1156231.

Figure $6 \quad$ Leptodinium sp.

Apical view; Section-358-8-3; 1137225.

Figure 7 Hystrichokolpoma rigaudae Deflandre and Cookson, 1955.

Apical view; Section 358-10-4; SL.2:99598.

Figure $8 \quad$ Hystrichokolpoma cinctum Klumpp, 1953.

Section 358-9-2; 106698.

Figure 9 Schematophora speciosa Deflandre and Cookson, 1955.

Apical view slightly offset, Section 358-5-1; 107040.

Figure 10 Cyclonephelium cf. reticulosum Gerlach, 1961. Section 358-6-3; 110366.

Figure 11 Thalassiphora succincta Morgenroth, 1966.

Section 358-6-3; 97353.

Figure 12 Deflandrea phosphoritica Eisenack, 1938.

Core 358-10, CC; 1113190.

Figure 13 Tuberculodinium vancampoae (Rossignol) Wall, 1967.

Section $358-5-3 ; 934214$.

Figure 14 ? Lejeunia $\mathrm{sp}$.

Section 358-7-2; 94970.

Figure $15 \quad$ Trichodinium castanea (Deflandre) Clarke and Verdier, 1967.

Section 356-39-5; SL. 1:1163222. 


\section{PLATE 1}

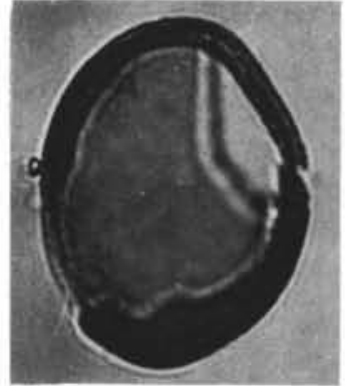

1

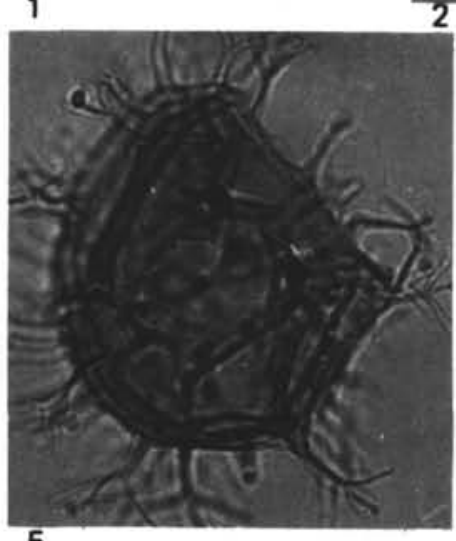

5

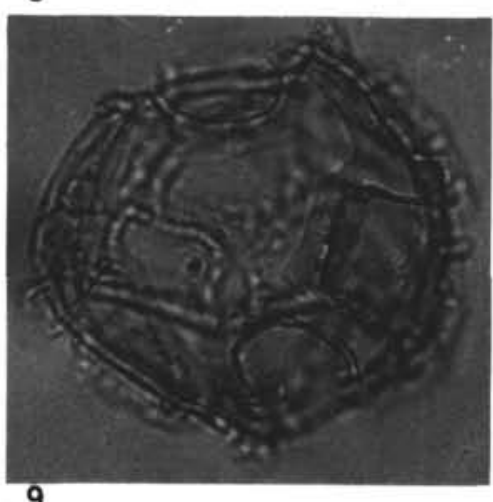

9

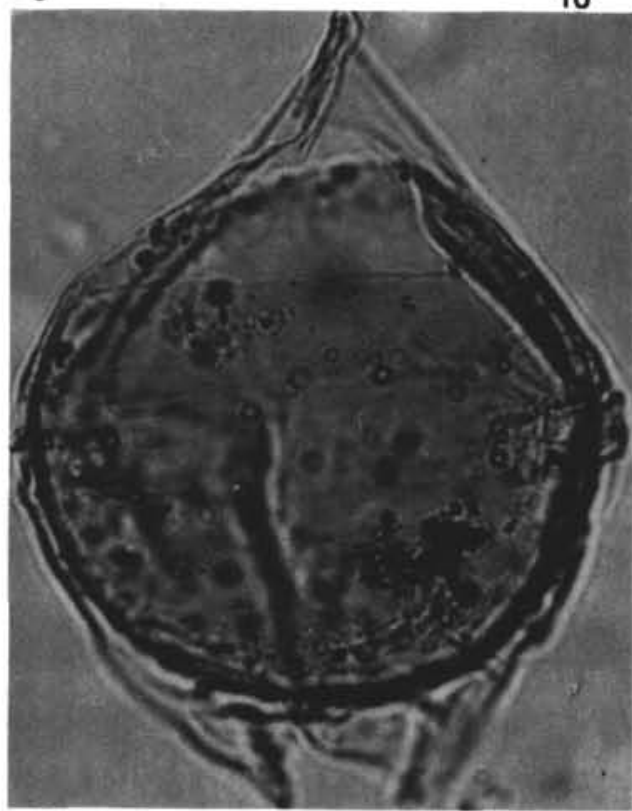

12

6
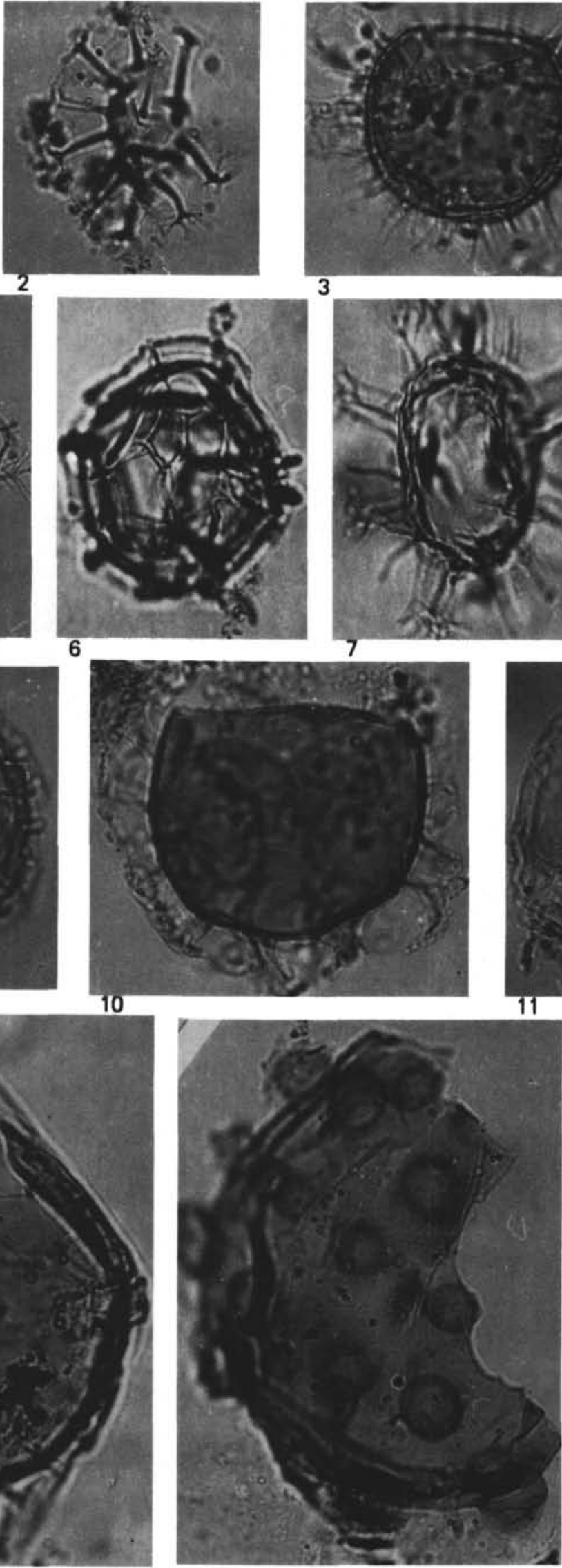

13

3
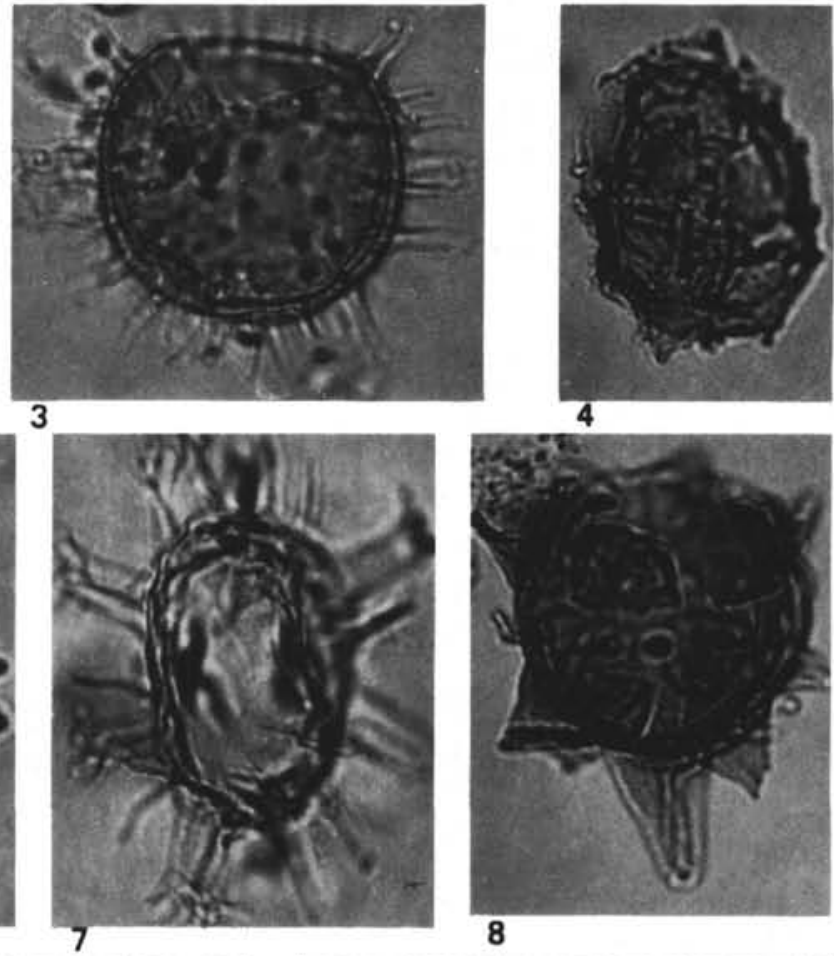

8
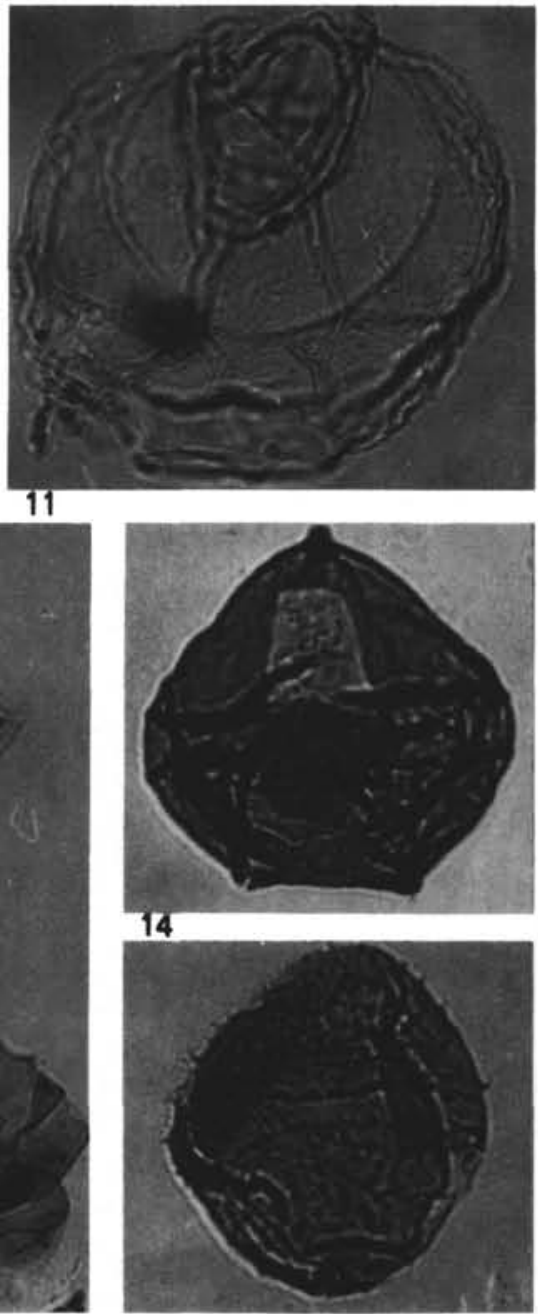
PLATE 2

All figures $\times 750$ unless otherwise stated.

Figure $1 \quad$ Fromea sp.

Section 356-38-1; 1090217.

Figure 2 Exochosphaeridium bifidum (Clarke and Verdier) Clarke, Davey, Sarjeant, and Verdier, 1968.

Precingular archaeopyle upwards; Section 356-381; 932156.

Figures 3, $4 \quad$ Heslertonia sp.

4. Detail showing striate septa, $\times 1000$, Section 356-38-1; 95580.

Figures 5,6 Silicisphaera buspina Davey and Verdier (in press). Speciment showing precingular archeopyle.

6. Phase contrast photograph showing structure of processes, $\times 1000$; Section 356-39-3; 1096120.

Figure 7 Conosphaeridium striatoconus Deflandre and Cookson, 1969.

Section 356-39-5; SL. 1:1135170.

Figures 8,9 Dinogymnium acuminatum Evitt, Clarke, and Verdier, 1967.

8. Section 356-39-4; SL. 1:1128202.

9. Section 356-39-4; SL. 2:111250.

Figures 10, 11 Pterodinium sp.

10. Dorsal view; Section 356-38-2; SL. 1:1057145.

11. Ventral view.

Figure 12 Deflandrea granulostriatum (Jain and Millepied) Herngreen, $1975 \mathrm{~b}$.

Section 356-39-3; 94479.

Figure $13 \quad$ Oviodinium sp.

Section 356-40-1; SL. 1:1106150.

Figure 14 Odontochitina operculata (O. Wetzel) Deflandre and Cookson, 1955.

Section 356-40-1; SL. 1:1023147. 
PLATE 2
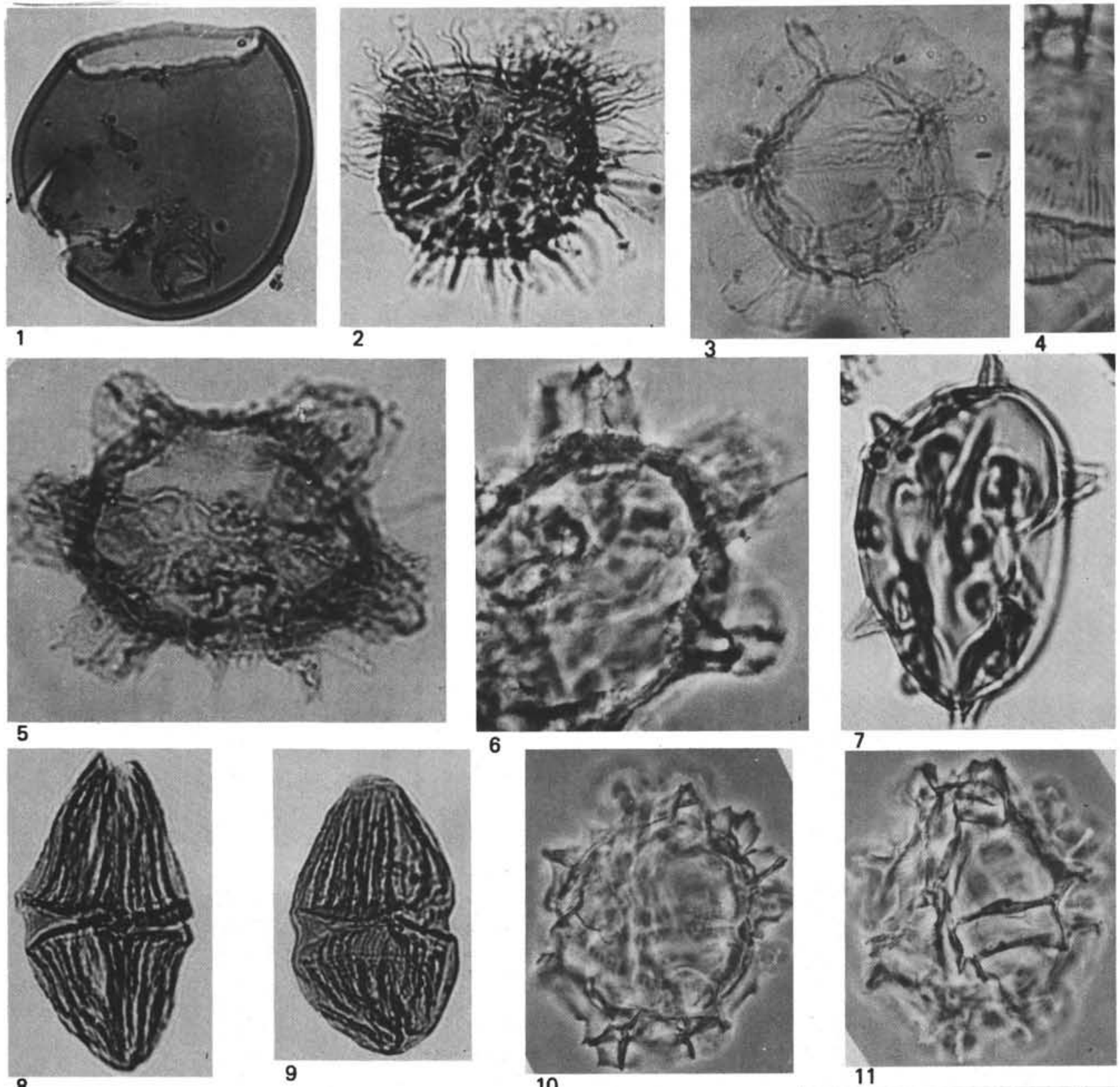

7
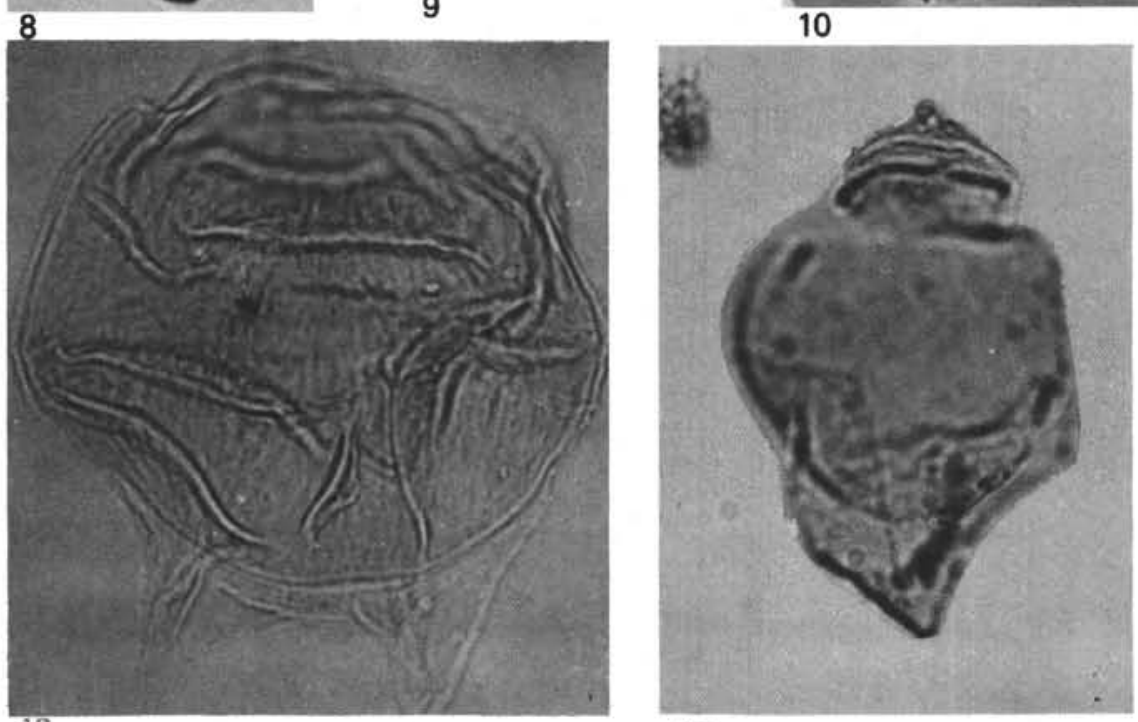
PLATE 3

All figures $\times 750$ unless otherwise stated

Figure 1 Deflandrea cf. acuminata Cookson and Eisenack 1958.

Apical horn appears folded over periphragm; Section 356-40-5; SL. 2:121038.

Figure 2 Cooksoniella cf. scheii (Manum) Lentin and Williams, 1973.

Section 356-40-1; SL.2:117252.

Figure 3 Deflandrea ?macrocysta Cookson and Eisenack, 1960.

Archaeopyle type 3 not clearly seen; Section 35639-5; SL. 2:108332.

Figures 4, 7,9, Pterospermopsis spp.

12

4. Section 355-15-1; 94440.

7. Section $355-15-1 ; 187137$.

9. Section $355-15-4 ; 1198148, \times 500$.

12. Section $355-15-1 ; 106852, \times 500$.

Figure $5 \quad$ Foveotricolpites prolatus Herngreen 1975a.

Section 356-39-4; SL.2:1023108.

Figure 6 Leiosphaeridia sp. (recorded by Harris, 1974, pl. 3, fig. 16).

Section 355-15-1; 102547.

Figure $8 \quad$ Tasmanites sp.

Specimen showing a very thick exine, Section 355 $15-4 ; 1198148$.

Figure $10 \quad$ Tythodiscus sp.

Section 355-15-1; 100954.

Figure $11 \quad$ Callialasporites cf. C. trilobatus Sukn Dev. 1961. Section 355-15-2; SL.1:1180128.

Figures 13, 14. ?Rugaepollis sp. Section 355-15-1; 102460, $\times 1000$.

13. Section 355-15-1; 1138106.

14. Detail to show the exine structure. 
PLATE 3
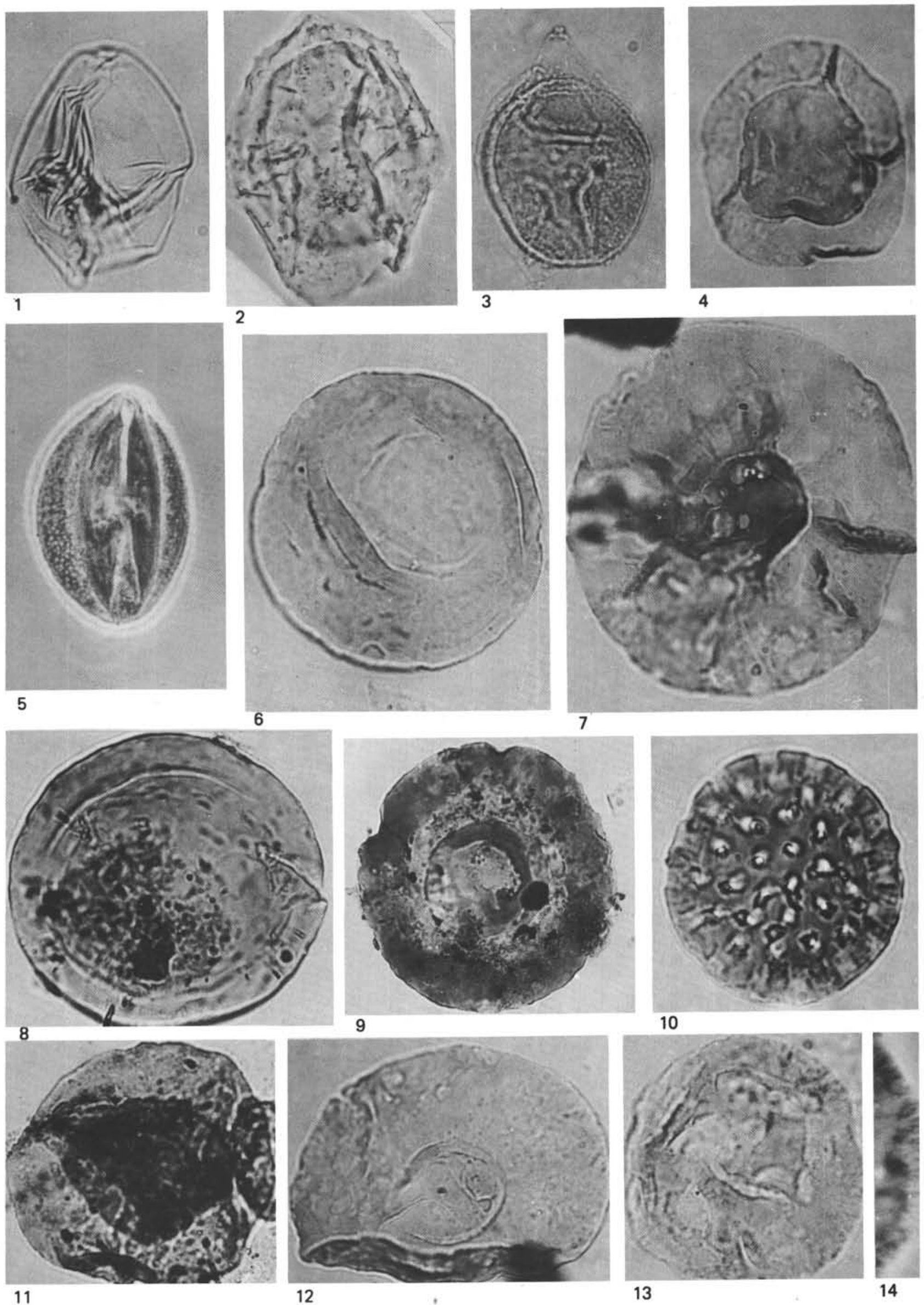


\section{PLATE 4}

All figures $\times 750$ unless otherwise stated

Figure 1

Figure 2

Figure 3

Figure 4

Figure 5

Figure 6

Figure 7

Figure 8

Figures 9, 11

Figure 10

Figure 12

Figure 13

Figure 14

Figures 15, 16

Figures 17, 18

$$
\begin{aligned}
& \text { Cyathidites minor Cooper, } 1958 . \\
& \text { Section 355-15-2; SL. 1:115582. }
\end{aligned}
$$

Concavissimisporites sp.

Section 355-15-2; SL. 1:955155.

Interulobites $\mathrm{sp}$. A.

Section 356-40-1; SL. 1:932121.

Interulobites $\mathrm{sp}$. B.

Section 356-40-1; SL. 2:1015227.

Undulatisporites $\mathrm{sp}$.

Section 356-39-4; SL. 1:102690.

Pilosisporites cf. trichopapillosus (Thiergart)

Delcourt and Sprumont, 1955.

Section 356-41-1; SL.1:116195.

Indeterminate $\mathrm{sp} .1$.

A form structurally similar to modern Schizeca but no germinal scar observed. Section 356-39-4; SL. 2: 108163 .

Ephedripites sp. A.

Showing spiral costae. Section 356-40-1; SL. 2:119035.

Rouseisporites cf. reticulatus Pocock 1962.

9. Section 356-39-4; SL. 2:115176.

11. Section 356-39-4; SL. 1:1184223.

Cerebropollenites mesozoicus (Cooper) Niltson, 1958.

Section 355-15-2; SL. 2:1046173.

Reticulitriletes heteroluminensis Boltenhagen, 1975b.

Section 356-40-1; SL. 2:1079223.

Cicatricosiporites $\mathrm{sp}$.

Section 356-39-4; SL. 1:1100258.

Tricolpites sp.

Section 356-39-2; SL. 1:102594.

Punctioratipollis krutzschi Boltenhagen, 1975.

15. Section 356-39-4; SL. 2:100740.

16. Section 356-39-4; SL.1:102146.

Classopollis sp.

Specimens showing concentric striations.

17. Section 356-40-1; SL.2:946107.

18. Section 356-40-1; SL. 1:947132.

Figure 19 Classopollis torosus (Reissinger) Balme, 1957.

Section 356-39-5; SL.2:120070.

Figures 20,21 Cf. Accuratipollis sp.

20. Specimen showing round out apical apertures; Section 356-39-4; SL. 1:103732.

21. Specimen showing slit-like apical apertures (trichotomosulcate); Section 356-40-1; SL. 2:946107. 
PLATE 4
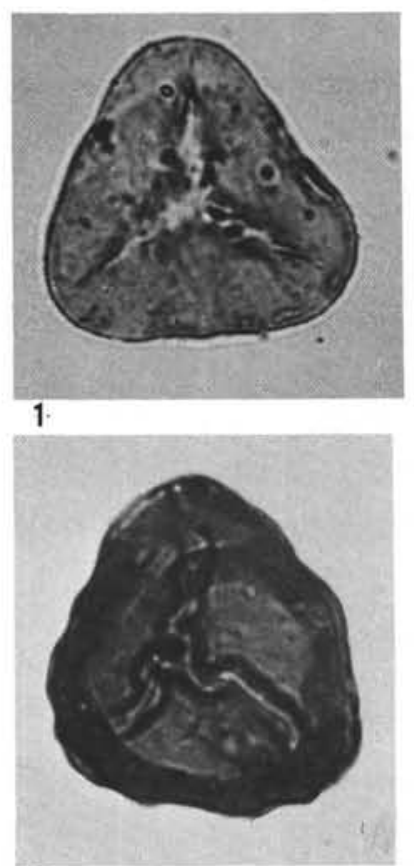

5
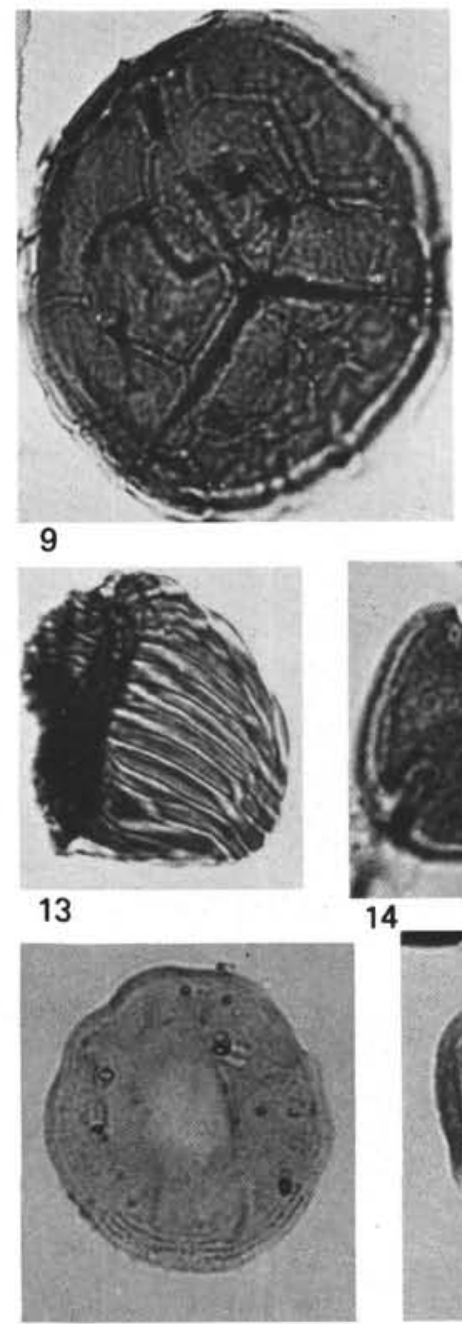

18

19
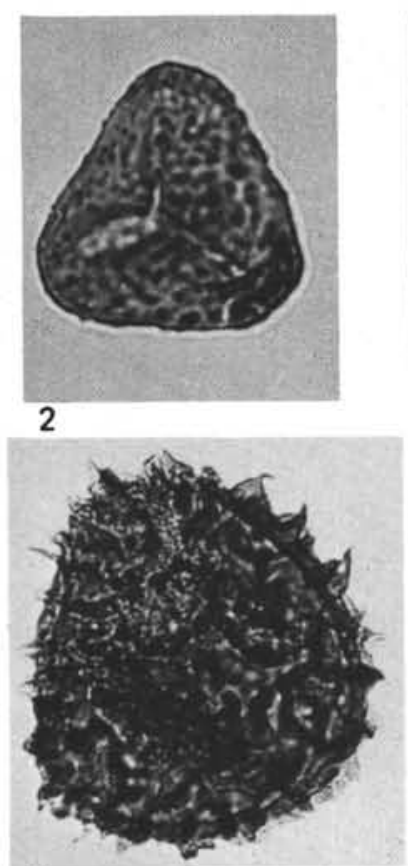

6

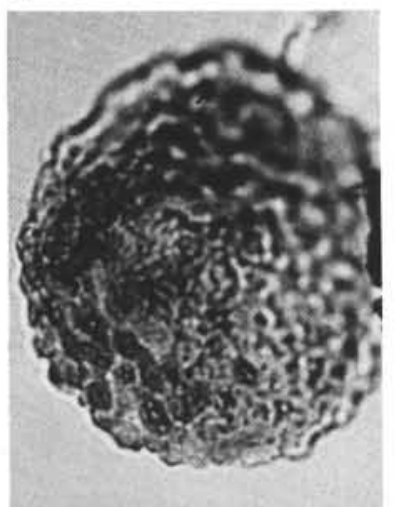

10
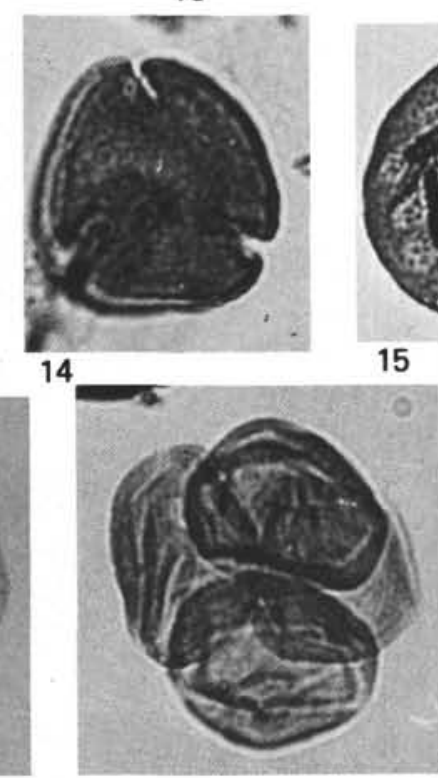

15
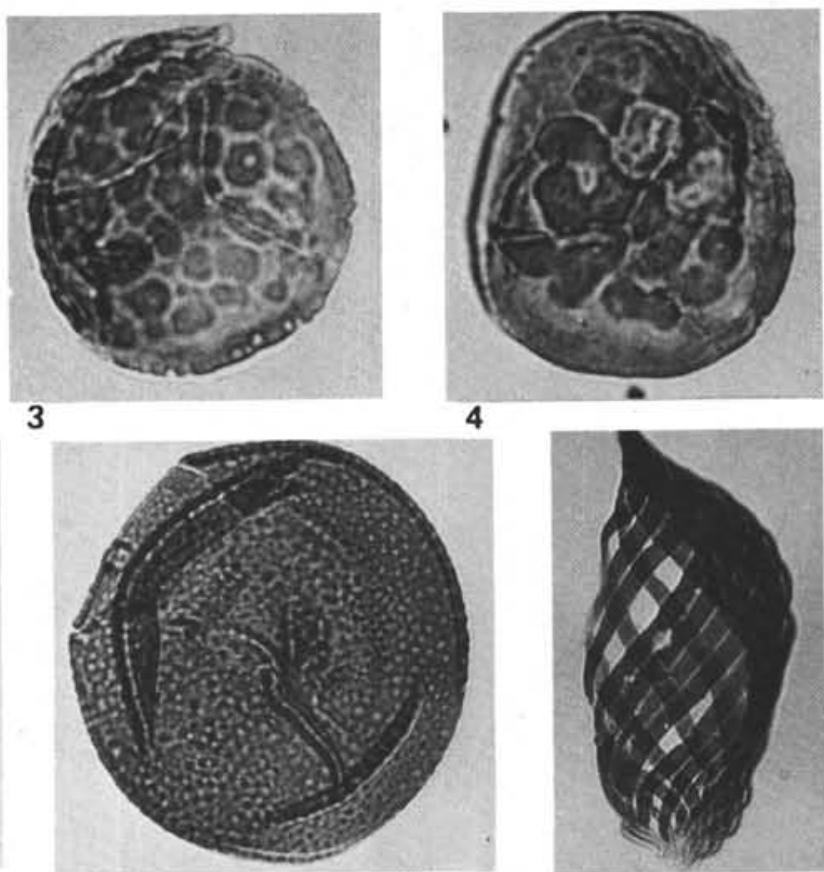

7

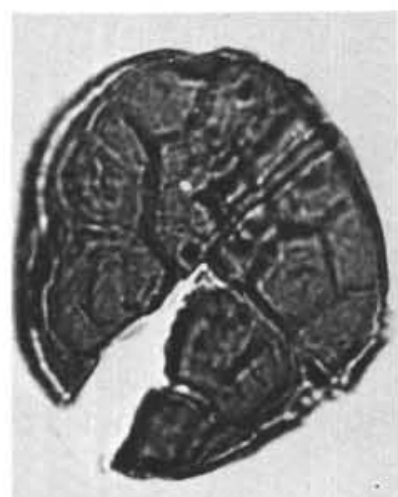

11
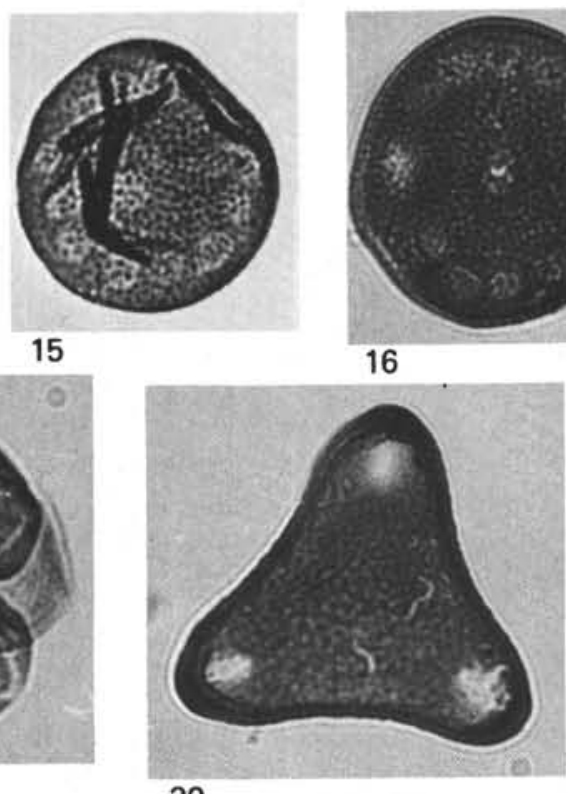

20

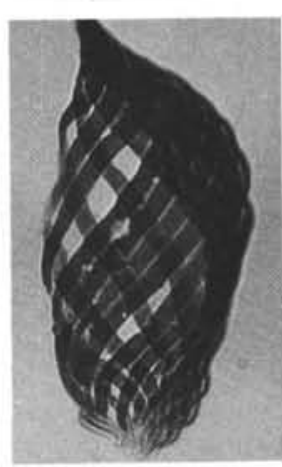

8

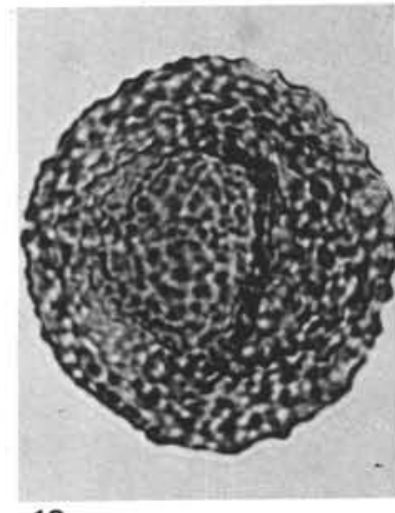

12
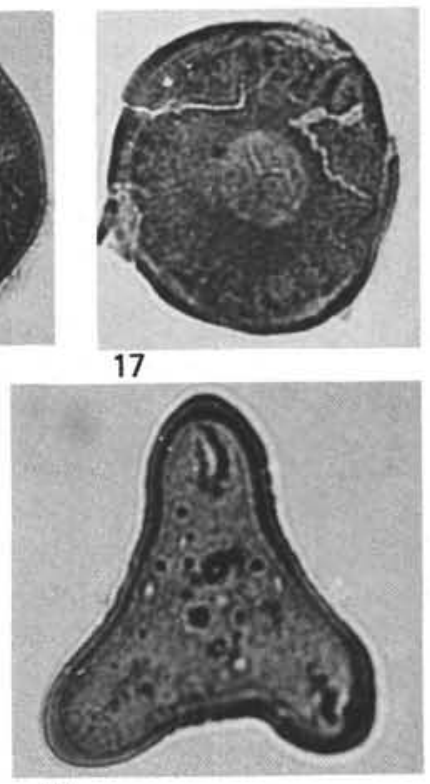